\title{
German academics find career boost in east
}

Munich. A survey carried out by Nature has confirmed that a large proportion of senior academic posts in higher education institutes in the former German Democratic Republic (GDR) have been given to west German academics.

The data were compiled from a survey of 57 east German institutions of higher education, including all major universities except the Humboldt University in Berlin and the Technical University of Dresden. Questionnaires were completed by 30 institutions.

The results reflect the success of efforts since reunification in 1990 to ensure that university posts are awarded to those best qualified to hold them. But they are also likely to fuel charges that west Germans are exploiting the situation in the east to further their own careers.

After reunification, the universities in the former eastern part of the country decided to adopt the west German higher education model, in which universities act as centres of both research and teaching, rather than being dedicated primarily to teaching.

As part of the change, all university teachers were checked for both their political and intellectual suitability to retain their posts. Those found to have actively collaborated with the Stasi, the former East Germany's secret police, or to be underqualified in western terms, were dismissed. Those remaining had to reapply for their posts through open competition.

Answers to the questionnaire show that in the politically neutral science subjects, the majority of the newly appointed academics are from the east; the proportion is two-thirds in science and technology, and

\begin{tabular}{|lrrr}
\multicolumn{4}{c}{$\begin{array}{c}\text { Statistical breakdown of higher education } \\
\text { staff in east Germany }\end{array}$} \\
Origin by faculty & East & West & Other* \\
Medicine and Vet. science & 78.0 & 19.8 & 2.2 \\
Science and Technology & 64.2 & 24.7 & 11.1 \\
Social sciences & 21.3 & 61.3 & 17.4 \\
Humanities & 34.2 & 42.9 & 22.9 \\
Economics & 31.9 & 45.6 & 22.5
\end{tabular}

Age 30-50

Universities

Fachhochschulen

29.5

42.2

47.4

C2 professors

C3 professors

56.1

39.1

C4 professors

21.6

53.0

$\begin{array}{ll}36.2 & 7.7\end{array}$

$47.7 \quad 13.1$

$55.8 \quad 22.6$

\section{Age 50+}

Universities

Fachhochschulen

C2 professors

C3 professors

C4 professors
23.1

4.8

nearly three-quarters in medicine and veterinary science.

In the more ideologically sensitive humanities, by contrast, west German academics dominate. In the social sciences, nearly two-thirds now come from the west, and in economics around half. Only 10 per cent of the new law faculties are staffed by east German professors.

Although the Humboldt University did not take part in the survey, the latest general figures show that just over half of those appointed to the 387 positions offered so far came from west Germany and 90 per cent of the remainder were originally from the Humboldt.

Behind the aggregate figures lie some significant trends. Most of the movement from west to east involves young academics. Nearly half of the newly appointed professors under 50 years of age are from the west, compared with fewer than 20 per cent who are older than 50 .

There is also a clear difference between the positions on the academic scale of academics under 50. Those on the highest rank (C4) are more likely to come from the west, while their eastern counterparts have had more success in competitions for lower rank positions.

And there is a clear difference between the types of higher education institutes. Whereas east Germans hold only 50 per cent of posts in universities, in the more techniorientated Fachhochschulen - institutes offering high-level vocational training - they hold 60 per cent of the posts. And east Germans have 70 per cent of the toplevel professorships in Fachhochschulen compared to only 40 per cent in the universities.

The question of the number of west German academics who have taken jobs in the new Länder is politically very sensitive, and one on which many in the west are reluctant to comment.

But Gert Maibaum, head of the universities section of the research ministry of Saxony (the largest of the five new Länder), says that the survey results are not unexpected. Given time, he says, east Germans will be able to compete effectively with their western colleagues.

Josef Langer, general secretary of the University Rectors' Conference, agrees. "There is no disappointment among rectors," he says, referring to the relatively low success of east Germans in competing for senior professorships.

There is, however, considerable disappointment among east German academics. Andre Hahn, education policy spokesman for the Party of Democratic Socialism (PDS) - the successor to the GDR's communist party - says that they were automatically at a disadvantage compared to their west German colleagues. For example, he says, the isolation of their community under communism meant that academics had less opportunity to publish their work in the scientific literature. Yet a major criterion for professorships was an applicant's publication record.

There is the serious danger that new professors coming from the west will stay in the east only for as long as it benefits their careers, and will leave as soon as a better opportunity arises in the west.

A similar outcome was found by $\mathrm{Na}$ ture's survey of non-university research establishments last year (Nature 362, 685; 1993) where most of the top jobs were snapped up by west Germans. In 1990, the science council (the Wissenschaftsrat) expressed the hope that there would be a "seeding" of these institutes with 10 per cent west Germans at all levels. But in fact few westerners took up lower positions.

Antje Langer

\section{German science funds hold out against cuts}

Munich. Paul Krüger, the German research minister, has persuaded his cabinet colleagues to approve a rise of 2.7 per cent in next year's research budget. If, as expected, this is endorsed by parliament, German research will have DM9.47 billion (US\$5.97 billion) of federal funds to distribute in 1995, DM250 million more than this year.

With an inflation rate of around 4 per cent, this still means a cutback in real terms. But it also means that research has done considerably better than other areas of public spending; next year's general budget will be kept down to a one per cent increase on this year.

Krüger says that he still intends to prioritize key technologies such as information and materials sciences and biotechnology, with increases of around 3 per cent and 9 per cent respectively. Environmental technologies will get an even larger increase of 10 per cent.

But basic science will not lose out. The research ministry will stick to its promise in 1990 to raise the Max Planck Society budget by 5 per cent for at least five years. Although only slightly higher than inflation, this agreement no longer appears as restrictive as it did a few years ago.

Alison Abbott 